\title{
Microflora associated with healthy and diseased turbot (Scophthalmus maximus) from three farms in northwest Spain
}

\author{
A.E. Toranzo ${ }^{a}$, B. Novoa ${ }^{b}$, J.L. Romalde ${ }^{a}$, S. Núñez ${ }^{a}$, S. Devesa ${ }^{c}$, E. Mariño ${ }^{c}$, \\ R. Silva ${ }^{c}$, E. Martinez ${ }^{\mathrm{d}}$, A. Figueras ${ }^{\mathrm{b}}$ and J.L. Barja ${ }^{\mathrm{a}}$ \\ ${ }^{a}$ Departamento de Microbiologia y Parasitologia, Facultad de Biologia, Universidad de \\ Santiago de Compostela, Spain \\ ${ }^{\mathrm{b}}$ Instituto Investigaciones Marinas, Vigo, Spain \\ ${ }^{\mathrm{c}}$ Neptune Acuicultura S.A., La Coruña, Spain \\ ${ }^{\mathrm{d}}$ Piscicola de1 Morrazo, Pontevedra, Spain
}

Correspondence to: A.E. Toranzo, Departamento de Microbiologia y Parasitologia, Facultad de Biologia, Universidad de Santiago de Compostela 15706, Spain. Tel. 34-8 1-563100 (\#2548); Fax: 34-8 1-596904

\section{ABSTRACT}

A comparative analysis of the microbiological quality of three turbot (Scophthalnus maximus) farms (A, B, and C) located in Galicia (northwest Spain) is given. The microbial load and types of bacteria in the internal organs (liver and kidney) of apparently healthy fish was monitored over a year, and all the disease problems occurring during this survey were analyzed. The percentage of healthy turbot in which positive bacterial growth was obtained was relatively high in the three ongrowing facilities. Farm A exhibited the poorest conditions of fish health with an average of $42 \%$ fish infected, while farm B showed the best microbiological quality with $27 \%$ of turbot harbouring bacteria in the internal organs. In all three farms, a wide range of bacteria was found in healthy turbot with Vibrio (V. splendidus-V pelagius, Vfisheri-V harveyi and Vibrio spp.) and Pseudomonas spp. being the predominant groups comprising at least $80 \%$ of the total bacterial isolates in each farm. 
The highest number of pathological problems (22) with the most diverse bacterial flora occurred in farm A. Vibrio spp. and Pseudomonas spp. were the most prevalent bacteria recovered from diseased turbot. Haemorrhages in palate and jaws, tail and fins, and ulcerative lesions were the most frequent external clinical signs of diseased fish recorded in the three farms. However, it was not possible to associate a particular bacterial species with a specific pathology. Routine use in farm A of oxolinic acid and nitrofurantoin may have led to the development in the Vibrio strains of resistances to both chemotherapeutants (up to $25 \%$ ).

\section{INTRODUCTION}

Since 1984 there has been a considerable increase in turbot (Scophthalmus maximus) culture in Galicia (northwest Spain) with the establishment of 20 rearing facilities of which only four are integrated farms. The production of turbot in Galicia in 1992 reached 1100 metric tons (t), and about $1500 \mathrm{t}$ is expected for 1993.

This rapid development of turbot culture has resulted in a concomitant appearance of pathological problems. Therefore, most of the studies in this fish species have focussed on the isolation and characterization of the aetiological agents (Devesa et al., 1989; Lupiani et al., 1989; Toranzo et al., 1990; Toranzo and Barja, 1990; Bloch et al., 1991; Fouz et al., 1992) as well as on the prevention and control of the diseases (Santos et al., 1991; Toranzo et al., 1992). However, other microbiological aspects concerning the microflora of healthy turbot have received little attention (Austin, 1982; Mudarris and Austin, 1988).

Detailed information about the microbial load and types of bacteria in the internal organs of apparently healthy fish is essential in order to recognize and correct the abnormal conditions (such as those attributed to adverse water and food quality factors or unfavourable management aspects) which can be a prelude to the appearance of an epizootic disease. With this aim in mind, a comparative study was conducted of the microbiological quality of three ongrowing turbot farms located in different "Rias" of Galicia. The pathological problems occurring in the fish stocks monitored throughout this survey were also analyzed, and the drug resistance patterns of the bacterial isolates determined. 


\section{MATERIALS AND METHODS}

Sampling locations and culture conditions

From April 1990 to April 1991 apparently healthy and also diseased turbot (Scophthalmus maximus) ranging in weight from $10 \mathrm{~g}$ to $500 \mathrm{~g}$ reared at three ongrowing farms (A, B, and C) located on different Rias of Galicia (NW Spain) were sampled. These sites were at least $30 \mathrm{~km}$ away from each other. Fish were maintained in concrete tanks with an aerated open-flow circuit. Turbot were stocked at a density of 5 $\mathrm{kg} / \mathrm{m}^{3}$ (for the smallest fish) and $20-25 \mathrm{~kg} / \mathrm{m}^{3}$ (for the larger size of fish). The water temperature in the three farms fluctuated between 12 and $18{ }^{\circ} \mathrm{C}$ (Fig. 1), but the salinity was practically constant at $34 \mathrm{ppt}$. Dissolved oxygen was maintained at saturation levels. Fish were fed with a semi-moist diet produced on the farms.

Sample processing and microbiological examination of the samples

Monthly samples were taken from 4-5 fish stocks in each facility. From each stock between 5 and 10 fish (depending on the size) were analyzed. About 300 healthy turbot were, therefore, sampled from each farm. The different pathological problems occurring in these farms during the sampling period were recorded and the fish were also subjected to microbiological analysis.

For bacterial isolation, samples of kidney and liver were taken under aseptic conditions and streaked directly onto plates of tryptic soy agar (TSA) (Difco) supplemented with $1 \% \mathrm{NaCl}$ (TSA-1), marine agar Z 2216 (MA) (Difco), and thiosulphate citrate bile sucrose (TCBS) agar (Oxoid). Plates were incubated for $48-72 \mathrm{~h}$ at $22^{\circ} \mathrm{C}$. To rule out the presence of Renibacterium salmoninarum, samples were also streaked onto Mueller Hinton agar (Difco) plus 0.1\% cysteine (MHA-C), and charcoal agar (KDM-C) plates which were maintained at $15{ }^{\circ} \mathrm{C}$ for at least 30 days. In addition, the isolation of fastidious marine Cytophaga-Flexibacter species was attempted in Anacker and Ordal medium and in the modified Shieh medium (Song et al., 1988) both prepared using sea water as the diluent. 
A representative number of the morphologically different colony types was isolated from each plate, and re-streaked on fresh TSA-1 medium to ensure purity. Working cultures were maintained in tubes of soft agar $(0.1 \%$ casitone, $0.3 \%$ yeast extract, $1 \%$ $\mathrm{NaCl}, 0.3 \%$ agar, $\mathrm{pH} 7.2$ ) under mineral oil. For long-term preservation, cultures were frozen at $-70^{\circ} \mathrm{C}$ in tryptic soy broth (TSB) (Difco) containing $1 \% \mathrm{NaCl}$ and $15 \%(\mathrm{v} / \mathrm{v})$ glycerol. In addition, smears from internal organs and lesions (in diseased fish) were examined using phase-contract microscopy and Gram staining as well as fluorescent antibody techniques (FAT) using labelled antiserum against R. salmoninarum.

In the case of diseased turbot, samples were also processed for virus isolation attempts, following standard procedures (Amos, 1985). The Chinook salmon embryo (CHSE214), bluegill fry (BF-2), and epithelioma papullosum cyprine (EPC) cell lines were utilized in the virological analysis.

Biochemical and serological characterization of the bacterial isolates

Pure cultures of the bacterial strains were subjected to standard morphological, physiological and biochemical plate and tube tests according to the procedures of West and Colwell (1984), Bryant et al. (1986) and Fouz et al. (1990). In the unreactive halophilic strains (mainly Vibrio and Pseudomonas), the modified O/F medium (ZOF) (Lemos et al., L 1985) was also utilized for the oxidation-fermentation tests of carbohydrates. Plates and tubes were incubated at $22{ }^{\circ} \mathrm{C}$ for up to 7 days. In parallel, the commercial miniaturized API-20E system (Biomerieux, Spain) was also employed using half strength sea water as diluent for the halophilic strains, and the results scored after $48 \mathrm{~h}$ at $22^{\circ} \mathrm{C}$.

The taxonomic positions of the bacterial isolates were determined mainly following the schemes of Amos (1985), and Bergey's Manual of Systematic Bacteriology (1984, 1986). For the characterization of the Vibrio strains, the criteria of West and Colwell (1984), and Myhr et al. (1991) were also utilized.

Drug resistance patterns of the isolates were determined by the disc diffusion method on MHA plates with $1 \% \mathrm{NaCl}$ added, using the following chemotherapeutic agents $\mu \mathrm{g} / \mathrm{disc}$ ): ampicillin (10), tetracycline (30), oxytetra cycline (30), chloramphenicol (30), 
streptomycin (10), oxolinic acid (2), trimethoprim-sulphametoxazole (23.75/1.25), and nitrofurantoin (300). Penicillin G (10) and the vibriostatic agent $\mathrm{O} / 129$ (150) were employed only for taxonomic purposes.

In the strains of Vibrio anguillarum and those belonging to the V. splendidus - V. pelagius groups, serological analysis was performed by the slide agglutination test (Toranzo et al., 1987) using the thermostable "O" antigens and rabbit antisera raised against reference strains of $\mathrm{V}$. anguillarum representatives of the ten $\mathrm{O}$ serotypes (from O1 to O10).

\section{RESULTS}

Monitoring the microbiological condition of the farms

The percentage of apparently healthy fish in which positive bacterial growth was obtained from internal organs was relatively high in the three ongrowing farms over the sampling period (Fig. 1). Farm A presented the poorest fish health conditions with an average of $42 \%$ of fish giving positive results in the microbiological analysis (in all the samples from this farm, at least $20 \%$ of the fish harboured an abundant bacterial load in liver and kidney). In contrast, farm B showed the best microbiological quality with an average of $27 \%$ of the sampled turbot containing bacteria in the internal organs. Farm $\mathrm{C}$ exhibited an intermediate level of infected fish (37\%).

In some cases, the high percentages of infected fish corresponded with periods of high temperature (i.e., samples from periods 3 to 7, farms A and C), but a direct relationship between number of fish bearing microorganisms and temperature could not be established (Fig. 1) .

A great diversity in the microbial flora was found in the three farms, with Vibrio and Pseudomonas comprising at least $80 \%$ of the total bacterial isolates in each farm (Fig. 2). Among the Vibrio population, V. splendidus -V. pelagius, V. Fisheri - V. harveyi, and unidentified Vibrio spp. were the bacterial groups isolated in the three ongrowing farms. Although different prevalences of these Vibrio species were observed among the farms, high levels of V. Pelagius and unidentified Vibrio spp. were always recovered in 
the three rearing facilities (Fig. 2). Vibrio anguillarum serotype $\mathrm{O} 1$ was only detected in farm A. The majority of the unidentified Vibrio spp. corresponded to unreactive bacteria for both the production of acid from carbohydrates and decarboxylation of amino acids. None of the strains belonging to the taxonomically related V. splendidus - V pelagius groups displayed cross-reaction with the antisera raised against the serotypes of $\mathrm{V}$. anguillarum.

The remaining bacterial groups illustrated in Fig. 2 (Aeromonas, Moraxells Acinetobacter and Gram-positive cocci and bacilli) were detected in very low proportions in the three farms $(15.1 \%, 16.8 \%$ and $9.8 \%$ respectively for farms $\mathrm{A}, \mathrm{B}$, and C). However, some differences were discernible among the farms: whereas Sarcina and Streptococcus were isolated in farm A, Staphylococcus and Gram-positive bacilli belonging to Corynebacterium spp. were only found in farms B and C. Yeast and fungi were detected only in farm $\mathrm{C}$.

Microbiological analysis of diseased turbot

The number of problems registered in cultured turbot during the year-long survey varied among the three farms monitored (Table 1, Fig. 3). Farm A displayed the highest number of disease cases (22) with a great diversity of associated bacteria. Although in this farm, mixed bacterial infections occurred frequently, vibrio spp. and Pseudomonas spp. were the predominant bacterial groups isolated, representing $68.5 \%$ and $16.7 \%$ respectively, of the isolates. In none of the farms $\mathrm{B}$ and $\mathrm{C}$, which presented a reduced number of pathological problems, these two genera were the only ones recovered from diseased turbot. In none of the farms did these mortalities show an epizootic character.

Ulcerative lesions and haemorrhages centred in palate, jaws, tail and fins, were the most frequent disease problems occurring in the three farms. However, it was not possible to associate a particular bacterial species with a specific pathological condition. In fact, V. anguillarum belonging to serotype $\mathrm{O} 1$ was isolated in pure culture from different haemorragic septicaemias only in farm B. In addition, filamentous gliding bacteria, tentatively assigned to Flexibacter spp. were only detected in farm A in smears taken from ulcerative and or haemorrhagic skin lesions, but with a low prevalence $(5.6 \%)$ (Table 1, Fig. 3). This microorganism could not be grown on culture media. 
Whereas in farm A, the internal organs of fish infested with the microsporidian Tetramicra brevifilum and those exhibiting tumours were invaded by a diverse bacterial flora, in farms B and C, no bacterial growth was obtained in the turbot impaired by these pathological conditions.

Using cell-culture techniques, no viral agents were detected in the diseased turbot. Viral particles were also not visualized in tumours by electron microscopy.

Drug resistance patterns of the bacteriaI isolates

The sensitivity to different chemotherapeutic agents was tested on a representative number of strains belonging to the bacterial groups isolated from both healthy and diseased turbot (Tables 2, 3 and 4). In farm A, which utilized quinolones and nitrofurans in the diet to arrest fish losses, resistances to oxolinic acid and nitrofurantoin ranging from $12.5 \%$ to $25 \%$ were found in Vibrio spp. (Table 2). However, in farms B and C, practically all the Vibrio strains were sensitive to these chemotherapeutants (Tables 3 and 4). Interestingly, despite the use of oxytetracycline in these two farms, no vibrios which were resistant to this antibiotic were isolated.

No resistance to chloramphenicol and potentiated sulfonamides was observed in the Vibrio population, but high levels of strains resistant to ampicillin and streptomycin were detected in this genus. However, it must be considered that these resistances are important phenotypic characteristics which are usually used to identify different Vibrio species.

In the three farms, a significant number of the Pseudomonas strains proved to be resistant to all the drugs tested, being simultaneously resistant to tetracyclines, chloramphenicol, oxolinic acid and potentiated sulfonamides, a pattern exhibited for about $25 \%$ of the isolates. Although the number of Grampositive cocci and bacilli tested was small (because of the low number of bacterial isolates), the strains were also quite resistant to the drugs assayed.

\section{DISCUSSION}


In this study, clear differences were observed among the rearing facilities in the incidence of infected fish (from $27 \%$ for farm B to $42 \%$ for farm A). However, Vibrio and Pseudomonas were the predominant bacterial groups recovered in the three farms from internal organs of apparently healthy turbot (Fig. 2). Similar results have been obtained by other authors for different marine fish (MacDonald et al., 1986; Tanasomwang and Muroga, 1988, 1989). It is possible that the quantitative and qualitative differences observed among the three turbot farms in our routine microbiological analysis could be a reflection of the distinct design of each farm, its water and food quality, as well as different management conditions.

The highest number of pathological problems, with the most diverse associated bacterial flora, occurred in farm A (Fig. 3, Table 1) in accordance with the poor health conditions found in this farm during the routine microbiological survey.

The taxonomic study conducted by Austin (1982) on the heterotrophic bacteria from different sources of a turbot farm (water tanks, slime, effluents, surface of healthy fish, and skin lesions) indicated that although a diverse array of bacterial taxa (51) was recovered, the prevalent genera were Vibrio spp., Photobacterium, gliding bacteria (Cytophaga-Flexibacter spp.) and Acinetobacter. The gliding bacteria were common in surface and skin lesions. In our study, however, filamentous gliding bacteria were only detected in diseased fish from farm A, albeit with low prevalence (Fig. 3); this could explain the failure to recover these fastidious microorganisms in culture media. However, infections by Cytophaga-Flexibacter spp. have increased over the past year in fish cultured in sea water in our area, and these were consistently associated with ulcerative lesions, external haemorrhagic areas, and gill diseases. This increase allowed us to successfully isolate these gliding bacteria in specific culture media (Toranzo et al., 1993).

A large number of strains belonging to different biotypes of $\mathrm{V}$. splendidus and $\mathrm{V}$. pelagius was isolated from apparently healthy and diseased fish on the three farms (Figs. 2 and 3). However, a clear distinction between the strains is often difficult because of the number of variable reactions existing between them (Toranzo and Barja, 1990; Castro et al., 1992) . Although these vibrios are not considered to be of 
pathogenic significance, they have recently been associated with disease in marine fish (Masumura et al., 1989; Fouz et al., 1990; Toranzo et al., 1990; Myhr et al., 1991) and shellfish (Castro et al., 1992). These Vibrio species are phenotypically related to V. anguillarum and can be designated V. anguillarum-related (VAR) organisms (Myhr et al., 1991).

None of the Vibrio strains belonging to these groups was serologically related to the major pathogenic serotypes of $\mathrm{V}$. anguillarum $(\mathrm{O} 1$ and $\mathrm{O} 2)$ throughout the world (Toranzo and Barja, 1990). However, it is possible that some of the V. splendidus biovar I exhibiting positive results for arginine dihydrolase and fermentation of sucrose, could belong to the remaining serotypes of V. anguillarum (from O3 to O10) (Sorensen and Larsen, 1986), as two V. splendidus associated with ulcerative lesions in farm A corresponded to the serotype 04 of V. anguillarum (Pazos et al., 1992).

Several cases of haemorrhagic areas in the palate and jaws and occasionally, eyes, occurred in farms A and B. This pathology, which resembles the enteric redmouth disease of salmonids produced by Yersinia ruckeri, has become a common problem in many turbot farms. Although the species V. damsela was the causative organism of this disease in some turbot farms (Fouz et al., 1992) this bacterium was not detected in the fish suffering these clinical signs in the present study.

A selective pressure exercised by the chemotherapeutic agents used in the rearing facilities was noted in the Vibrio population for oxolinic acid and nitrofurantoin. The use of these drugs to control disease problems in farm A may have led to the development of Vibrio strains resistant to these two chemotherapeutants (Table 2). The rapid appearance of resistance to quinolones and nitrofurans caused by use of these drugs in fish farms has also been described mainly for Aeromonas salmonicida (Tsoumas et al., 1989) and V. anguillarum (Aoki et al., 1981).

A significant proportion of the Pseudomonas and Gram-positive bacteria proved to be resistant to the drugs usually employed in aquaculture; this seems to be a common feature of the strains of those genera isolated from fish culture systems (Toranzo et al., 1992), and indicates the difficulty of treating septicaemias caused by these multiresistant microorganisms. 
All these findings support the necessity of searching for alternative drugs which could be useful in controlling fish diseases in aquaculture. On the other hand, an adequate policy on the responsible use of drugs in aquaculture to arrest fish losses will help to minimize the development and spread of microorganisms carrying $\mathrm{R}^{+}$factors which may confer drug resistance to otherwise susceptible bacterial species.

\section{ACKNOWLEDGEMENTS}

The authors acknowledge the farms for the facilities provided during the sampling period as well as the supply of the turbot needed for the microbiological analysis. Some reference strains of $\mathrm{V}$. anguillarum and the corresponding antisera were a gift from Dr. J.L. Larsen, Department of Veterinary Microbiology, The Royal Veterinary and Agricultural University, Frederiksberger C, Denmark.

This study was supported by Grants MAR 91-1133 CO2-01 and MAR 89-0270 from the Comision Interministerial de Ciencia y Tecnologia (CICYT), XUGA 8030389 from Xunta de Galicia (Spain), and EUREKA project No. EU-347, between Spain and Norway.

B. Novoa thanks the Ministerio de Educacion y Ciencia (Spain) for a research fellowship.

\section{REFERENCES}

Amos, K.H. (Editor), 1985. Procedures for the Detection and Identification of Certain Fish Pathogens, 3rd edn. Fish Health Section, American Fisheries Society, Corvallis, OR, $114 \mathrm{pp}$.

Aoki, T., Kitao, T. and Kawano, K., 1981. Changes in drug resistance of Vibrio anguillarum in cultured ayu, Plecoglossus altivelis Temminck \& Schlegel, in Japan. J. Fish Dis., 4: 223-230.

Austin, B., 1982. Taxonomy of bacteria isolated from a coastal, marine fish-rearing unit. J. Appl. Bacterial., 53: 253-268. 
Bergey's Manual of Systematic Bacteriology, 1984 and 1986. Williams and Wilkins, Baltimore, USA, Vol. 1 (964 pp.) and Vol. 2 (635 pp.).

Bloch, B., Gravningen, K. and Larsen, J.L., 1991. Encephalomyelitis among turbot associated with a picornavirus-like agent. Dis. Aquat. Org., 10: 65-70.

Bryant, T.N., Lee, J.V., West, P.A. and Colwell, R.R., 1986. Numerical classification of species of Vibrio and related genera. J. Appl. Bacterial., 6 1: 437-496.

Castro, D., Martinez-Manzanares, E., Luque, A., Fouz, B., Moriñigo, M.A., Borrego, J.J. and Toranzo, A.E., 1992. Characterization of strains related to brown ring disease outbreaks in Southwestern Spain. Dis. Aquat. Org., 14: 229-236.

Devesa, S., Barja, J.L. and Toranzo, A.E., 1989. Ulcerative and fin lesions in reared turbot, Scophthalmus maximus (L.). J. Fish Dis., 12: 323-333.

Fouz, B., Conchas, R.F., Bolinches, J., Romalde, J.L., Barja, J.L. and Toranzo, A.E., 1990. Relationship among pathogenic Vibrio anguillarum and K tubiashii with environmental vibrios. In: F.O. Perkins and T.C. Cheng (Editors), Pathology in Marine Science. Academic Press, New York, pp. 77-89.

Fouz, B., Larsen, J.L., Nielsen, B., Barja, J.L. and Toranzo, A.E., 1992. Characterization of Vibrio damsela strains isolated from turbot (Scophthalmus maximus) in Spain. Dis. Aquat. Org., 12: 155-166.

Lemos, M.L., Toranzo, A.E. and Barja, J.L., 1985. Modified medium for the oxidationfermentation test in the identification of marine bacteria. Appl. Environ. Microbial., 49: 1541-1543.

Lupiani, B., Dopazo, C.P., Ledo, A., Fouz, B., Barja, J.L., Hetrick, F.M. and Toranzo, A.E., 1989. New syndrome of mixed bacterial and viral etiology in cultured turbot Scophthalmus maximus. J. Aquat. Anim. Health, 1: 197-204.

MacDonald, N.L., Stark, J.R. and Austin, B., 1986. Bacterial microflora in the gastrointestinal tract of Dover sole (Solea solea L.), with emphasis on the possible role of bacteria in the nutrition of the host. FEMS Microbial. Lett., 35: 107-111.

Masumura, K., Yasunobu, H., Okada, N. and Muroga, K., 1989. Isolation of a Vibrio sp., the causative bacterium of intestinal necrosis of Japanese flounder larvae. Fish Pathol., 24: 135- 141.

Mudarris, M. and Austin, B., 1988. Quantitative and qualitative studies of the bacterial microflora of turbot, Scophthalmus maximus L., gills. J. Fish Biol., 32: 223-229. 
Myhr, E., Larsen, J.L., Lillehaug, A., Gudding, R., Heum, M. and Hästein, T., 1991. Characterization of Vibrio anguillurum and closely related species isolated from farmed fish in Norway. Appl. Environ. Microbial., 57: 2750-2757.

Pazos, F., Santos, Y., Magariños, B. and Toranzo, A.E., 1992. Taxonomical and serological relationship among Vibrio species isolated from fish. Fifth Int. Coll. Pathol. Mar. Aquacult. (PAMAQ 5), Montpellier, France, p. 45.

Santos, Y., Bandin, I., Nuñez, S., Gravningen, K. and Toranzo, A.E., 1991. Protection of turbot, Scophthalmus maximus (L.), and rainbow trout, Oncorhynchus mykiss (Richardson), against vibriosis using two different vaccines. J. Fish Dis., 14: 409-4 14.

Song, Y.L., Fryer, J.L. and Rohovec, J.S., 1988. Comparison of six media for the cultivation of Flexibacter columnaris. Fish Pathol., 23: 91-94.

Sorensen, U.B.S. and Larsen, J.L., 1986. Serotyping of Vibrio anguillarum. Appl. Environ. Microbiol., 5 1: 593-597.

Tanasomwang, V. and Muroga, K., 1988. Intestinal microflora of larval and juvenile stages in Japanese flounder (Paralichthys olivaceus). Fish Pathol., 23: 77-83.

Tanasomwang, V. and Muroga, K., 1989. Intestinal microflora of rockfish Sebastes schlegeli, tiger puffer Takifugu rubripes and red grouper Epinephelus akaara at their larval and juvenile stages. Nippon Suisan Gakkaishi, 55: 1371-1377.

Toranzo, A.E. and Barja, J.L., 1990. A review of the taxonomy and seroepizootiology of Vibrio anguillarum, with special reference to aquaculture in the northwest of Spain. Dis. Aquat. Org., 9: 73-82.

Toranzo, A.E., Baya, A.M., Roberson, B.S., Barja, J.L., Grimes, D.J. and Hetrick, F.M., 1987. Specificity of slide agglutination test for detecting bacterial fish pathogens. Aquaculture, 67: 81-97.

Toranzo, A.E., Santos, Y., Bandin, I., Romalde, J.L., Ledo, A., Fouz, B. and Barja, J.L., 1990. Five-year survey of bacterial fish infections in continental and marine aquaculture in Northwest Spain. World Aquacult., 21: 91-94.

Toranzo, A.E., Romalde, J.L., Bandin, I., Santos, Y. and Barja, J.L., 1992. Evaluation of the sensitivity of bacterial fish pathogens to different antimicrobial compounds. In: C. Michel and D.J. Alderman (Editors), Chemotherapy in Aquaculture: from theory to reality. Office International des Epizooties (OIE), Paris, France, pp. 315-325. 
Toranzo, A.E., Barta, J.L. and Devesa, S., 1993. An overview of the main infectious problems in cultured turbot: present status and future necessities. Proc. World Aquaculture 93, Torremolinos, Spain. E.A.S. Spec. Publ. No. 19, p. 614.

Tsoumas, A., Alderman, D.J. and Rodgers, C.J., 1989. Aeromonas salmonicidu: development of resistance to 4-quinolone antimicrobials. J. Fish Dis., 12: 493-507. West, P.A. and Colwell, R.R., 1984. Identification and classification of Vibrionaceae, an overview. In: R.R. Colwell (Editor), Vibrios in the Environment. John Wiley and Sons Inc., New York, pp. 285-363. 
Fig. 1. Percentage of apparently healthy fish harbouring bacteria in the internal organs, in the three ongrowing turbot farms monitored during a year-long survey. (- $\square-$ ), water temperature,

Fig. 2. Comparison of the microbiological diversity found in the internal organs of healthy turbot in the routine survey conducted in the three ongrowing farms.

Fig, 3. Microflora associated with the different disease problems occurring in the three turbot farms during the sampling period.

\section{TABLE 1}

Microbiological analysis of diseased turbot during the period of study

\begin{tabular}{|c|c|c|c|}
\hline $\begin{array}{l}\text { Pathological } \\
\text { problem }\end{array}$ & $\begin{array}{l}\text { No. of } \\
\text { cases }\end{array}$ & Associated bacteria & $\begin{array}{l}\text { Isolation in pure } \\
\text { culture or mixed } \\
\text { infection }\end{array}$ \\
\hline \multicolumn{4}{|l|}{ FARM A } \\
\hline $\begin{array}{l}\text { Haemorrhages in } \\
\text { palate and jaws }\end{array}$ & 4 & $* \mathrm{~V}$. pelagius & $\begin{array}{l}\text { Different mixed } \\
\text { infections }\end{array}$ \\
\hline & & $\begin{array}{l}\text { V. fisheri } \\
\text { *Pseudomonas } \\
\text { Staphylococcus }\end{array}$ & \\
\hline $\begin{array}{l}\text { Haemorrhages in tail } \\
\text { and fins }\end{array}$ & 1 & $\begin{array}{l}\text { *Pseudomonas/Staphylococcus/ } \\
\text { Flexibacter }\end{array}$ & Mixed infection \\
\hline Ulcerative lesions & 7 & $\begin{array}{l}\text { *V. pelagius } \\
\text { V. fisheri } \\
\text { Vibrio spp. } \\
\text { *Pseudomonas } \\
\text { Streptococcus }\end{array}$ & $\begin{array}{l}\text { Different mixed } \\
\text { infections }\end{array}$ \\
\hline
\end{tabular}




\begin{tabular}{|c|c|c|c|}
\hline & & Flexibacter & \\
\hline \multirow[t]{5}{*}{ Turnours } & 2 & V. pelagius & Pure cultures \\
\hline & 1 & Vibrio sp. & Pure cultures \\
\hline & 1 & V. pelagius & Pure cultures \\
\hline & 1 & Moraxella-Acinetobacter & Pure cultures \\
\hline & 1 & V pelagius/Pseudomonas & Mixed infection \\
\hline \multirow[t]{3}{*}{$\begin{array}{l}\text { Microsporidian } \\
\text { infestation }\end{array}$} & 3 & V pelagius & $\begin{array}{l}\text { Different mixed } \\
\text { infections }\end{array}$ \\
\hline & & $\begin{array}{l}\text { V fisheri } \\
* \text { Vibrio spp. } \\
\text { Pseudomonas }\end{array}$ & \\
\hline & 1 & No bacterial growth & \\
\hline \multicolumn{4}{|l|}{ FARM B } \\
\hline \multirow[t]{2}{*}{$\begin{array}{l}\text { Haemorrhages in } \\
\text { palate and jaws }\end{array}$} & 2 & $\mathrm{~V}$ anguillarum $(01)^{\mathrm{a}}$ & Pure cultures \\
\hline & 1 & *Pseudomonas/Vibrio spp. & Mixed infection \\
\hline $\begin{array}{l}\text { Haemorrhages in tail } \\
\text { and fins }\end{array}$ & 2 & V. anguillarum $(01)$ & Pure cultures \\
\hline $\begin{array}{l}\text { Microsporidian } \\
\text { infestation }\end{array}$ & 2 & No bacterial growth & \\
\hline $\begin{array}{l}\text { Mortalities without } \\
\text { symptoms }\end{array}$ & 2 & Pseudomonas & Pure cultures \\
\hline FARM C & & & \\
\hline $\begin{array}{l}\text { Haemorrhages in tail } \\
\text { and tins }\end{array}$ & 1 & V. pelagius & Pure cultures \\
\hline \multirow[t]{2}{*}{ Ulcerative lesions } & 1 & Pseudomonas & Pure cultures \\
\hline & 1 & Pseudomonas spp. & Mixed infection \\
\hline Tumours & 1 & No bacterial growth & \\
\hline
\end{tabular}

*Predominant bacteria isolated in the mixed infections.

${ }^{a}$ Serotype. 
TABLE 2

Percentage of strains resistant to different chemotherapeutic agents isolated in turbot farm A

\begin{tabular}{|c|c|c|c|c|c|c|c|c|c|c|}
\hline \multirow[t]{2}{*}{ Bacteria } & \multirow{2}{*}{$\begin{array}{l}\text { No. tested/ } \\
\text { No. total } \\
\text { isolates }\end{array}$} & \multicolumn{9}{|c|}{ Drugs $^{a}$} \\
\hline & & $\mathrm{Am}$ & $\mathrm{Te}$ & OT & $\mathrm{C}$ & $\mathrm{S}$ & $\mathrm{OA}$ & Sxt & $F$ & $\mathrm{P}$ \\
\hline V. anguillarum & $1 / 1$ & 100 & 0 & 0 & 0 & 100 & 0 & 0 & 0 & $\mathrm{NT}^{\mathrm{b}}$ \\
\hline V. splendidus & $4 / 7$ & 25 & 0 & 0 & 0 & 50 & 25 & 0 & 25 & NT \\
\hline V. pelagius & $25 / 32$ & 25 & 0 & 0 & 0 & 66.7 & 16.1 & 0 & 16.7 & NT \\
\hline $\mathrm{V}$ fisheri- $\mathrm{V}$ & $18 / 26$ & 87.5 & 0 & 0 & 0 & 15 & 12.5 & 0 & 12.5 & NT \\
\hline \multicolumn{11}{|l|}{ harveyi } \\
\hline Vibrio spp. & $34 / 49$ & 42.8 & 0 & 0 & 0 & 100 & 17.6 & 0 & 17.6 & NT \\
\hline Aeromonas & $1 / 1$ & 0 & 0 & 0 & 0 & 100 & 0 & 100 & 0 & NT \\
\hline Pseudomonas & $10 / 20$ & 30 & 30 & 20 & 10 & 30 & 20 & 50 & 70 & NT \\
\hline Moraxella- & $1 / 7$ & 0 & 0 & 0 & 0 & 100 & 0 & 100 & 100 & NT \\
\hline \multicolumn{11}{|l|}{ Acinetobacter } \\
\hline Streptococcus & $1 / 4$ & 0 & 0 & 0 & 0 & 0 & 0 & 0 & 0 & 100 \\
\hline Staphylococcus & $1 / 3$ & 0 & 0 & 0 & 0 & 0 & 100 & 0 & 0 & 100 \\
\hline Micrococcus & $2 / 4$ & 0 & 50 & 50 & 50 & 100 & 100 & 0 & 50 & NT \\
\hline Sarcina & $1 / 2$ & 0 & 100 & 100 & 0 & 100 & 100 & 100 & 100 & NT \\
\hline
\end{tabular}

${ }^{\mathrm{a}} \mathrm{Am}$, ampicillin; Te, tetracycline; OT, oxytetracycline; $\mathrm{C}$, chloramphenicol; S, streptomycin; OA, oxolinic acid; Sxt, trimethoprim/sulphamethoxazole; F, nitrofurantoin; $\mathrm{P}$, penicillin $\mathrm{G}$.

${ }^{b} \mathrm{NT}$, not tested. 


\section{TABLE 3}

Percentage of strains resistant to different chemotherapeutic agents, isolated in turbot farm B*

\begin{tabular}{lllllllllll}
\hline Bacteria & No. tested/ & \multicolumn{1}{l}{ Drugs $^{\mathrm{a}}$} \\
\cline { 4 - 11 } & No. total isolates & $\mathrm{Am}$ & $\mathrm{Te}$ & $\mathrm{OT}$ & $\mathrm{C}$ & $\mathrm{S}$ & $\mathrm{OA}$ & $\mathrm{Sxt}$ & $\mathrm{F}$ & $\mathrm{P}$ \\
\hline V. anguillarum & $4 / 4$ & 100 & 0 & 0 & 0 & 100 & 0 & 0 & 0 & $\mathrm{NT}^{\mathrm{b}}$ \\
V. splendidus & $2 / 6$ & 0 & 0 & 0 & 0 & 0 & 0 & 0 & 0 & $\mathrm{NT}$ \\
V. pelagius & $11 / 11$ & 0 & 0 & 0 & 0 & 54.5 & 0 & 0 & 0 & $\mathrm{NT}$ \\
V fisheri-V. harveyi & $3 / 4$ & 33.3 & 0 & 0 & 0 & 66.6 & 0 & 0 & 0 & $\mathrm{NT}$ \\
Vibrio spp. & $16 / 17$ & 0 & 0 & 0 & 0 & 62.5 & 6.25 & 0 & 0 & $\mathrm{NT}$ \\
Aeromonas & $2 / 2$ & 100 & 0 & 0 & 0 & 100 & 0 & 0 & 0 & $\mathrm{NT}$ \\
Pseudomonas & $9 / 15$ & 55.5 & 22.2 & 33.3 & 55.5 & 66.6 & 44.4 & 55.5 & 66.6 & $\mathrm{NT}$ \\
Moraxella-Acinetobacter & $3 / 3$ & 0 & 0 & 0 & 0 & 100 & 100 & 0 & 0 & $\mathrm{NT}$ \\
Staphylococcus & $1 / 1$ & 0 & 0 & 100 & 100 & 0 & 100 & 100 & 0 & $\mathrm{NT}$ \\
Micrococcus & $3 / 3$ & 0 & 33.3 & 0 & 33.3 & 0 & 33.3 & 33.3 & 0 & 33.3 \\
Corynebacterium & $1 / 1$ & 100 & 100 & 100 & 100 & 100 & 100 & 100 & 100 & 100 \\
\hline
\end{tabular}

*See abbreviations in Table 2 . 


\section{TABLE 4}

Percentage of strains resistant to different chemotherapeutic agents, isolated in turbot farm $\mathrm{C}^{*}$

\begin{tabular}{|c|c|c|c|c|c|c|c|c|c|c|}
\hline \multirow[t]{2}{*}{ Bacteria } & \multirow{2}{*}{$\begin{array}{l}\text { No. tested/ } \\
\text { No. total isolates }\end{array}$} & \multicolumn{9}{|c|}{ Drugs $^{\mathrm{a}}$} \\
\hline & & $\mathrm{Am}$ & $\mathrm{Te}$ & OT & $\mathrm{C}$ & $\mathrm{S}$ & OA & Sxt & $\mathrm{F}$ & $\mathrm{P}$ \\
\hline V. Pelagius & $5 / 10$ & 20 & 0 & 0 & 0 & 40 & 0 & 0 & 0 & $\mathrm{NT}^{\mathrm{b}}$ \\
\hline V fisheri-V. harveyi & $2 / 2$ & 100 & 0 & 0 & 0 & 0 & 0 & 0 & 0 & NT \\
\hline Vibrio spp. & $18 / 18$ & 0 & 0 & 0 & 0 & 77.7 & 0 & 0 & 0 & NT \\
\hline Pseudomonas & $1 / 1$ & 31.2 & 31.2 & 25 & 31.2 & 18.7 & 18.7 & 50 & 18.7 & NT \\
\hline Moraxella-Acinetobacter & $1 / 1$ & 0 & 100 & 100 & 0 & 0 & 100 & 0 & 0 & NT \\
\hline Staphylococcus & $1 / 1$ & 0 & 100 & 100 & 0 & 100 & 100 & 100 & 100 & NT \\
\hline Micrococcus & $1 / 1$ & 0 & 100 & 100 & 0 & 100 & 100 & 100 & 100 & 100 \\
\hline Corynebacterium & $3 / 3$ & 100 & 0 & 0 & 33.3 & 100 & 0 & 33.3 & 0 & NT \\
\hline
\end{tabular}

*See abbreviations in Table 2. 